\title{
Handbook of Pultrusion Technology
}

Raymond W. Meyer, B. S. Ch. E.,

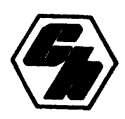

Chapman and Hall

New York London 
First published 1985

by Chapman and Hall

29 West 35th St. New York, NY 10001

Published in Great Britain by

Chapman and Hall Ltd

11 New Fetter Lane, London EC4P 4EE

(C) 1985 Chapman and Hall

Softcover reprint of the hardcover 1st edition 1985

All Rights Reserved. No part of this book may be reprinted, or reproduced or utilized in any form or by any electronic, mechanical or other means,

now known or hereafter invented, including photocopying and recording, or in any information storage or retrieval system, without permission in writing from the publishers.

\section{Library of Congress Cataloging in Publication Data}

Meyer, Raymond W., 1918-

Pultrusion technology handbook.

Bibliography: $p$.

Includes index.

1. Pultrusion. I. Title.

TP1175.P84M49 1985

$668.4^{\prime} 94 \quad 85-3828$

ISBN 978-1-4684-7766-5

DOI 10.1007/978-1-4684-7764-1

ISBN 978-1-4684-7764-1 (eBook) 


\section{Table of Contents}

Chapter 1: General Information $\quad 1$

Description of Pultrusion Composite 1

Description of Pultrusion Process 3

Description of Pultrusion Machine 3

History of the Pultrusion Process $\quad 7$

$\begin{array}{ll}\text { Pultrusion Markets } & 7\end{array}$

Chapter 2: Pultrusion Part Design 13

FRP Mechanical Property Design Criteria 13

Structural Shapes $\quad 20$

Hollow Shapes 23

Pultrusion Part Standard Tolerances $\quad 23$

Fabrication Techniques $\quad 28$

Mechanical Fasteners $\quad 32$

Adhesive Bonding 32

Pultruded Product Case Histories $\quad 38$

Chapter 3: Pultrusion Die Design 41

Introduction 41

Pultrusion Die Design Suggestions $\quad 42$

Specific Pultrusion Die Design Criteria 42

Special Pultrusion Die Considerations $\quad 50$

Chapter 4: FRP Raw Materials 51

Introduction 51

Unsaturated Polyester Resins 51 
iv Handbook of Pultrusion Technology

Other Resins $\quad 60$

Thermoplastic Additives 62

Inorganic Fillers $\quad 64$

Fibrous Reinforcements $\quad 76$

Organic Peroxides 84

Internal Release Agents $\quad 87$

Pigments $\quad 88$

Additives 90

Surfacing Mats and Veils $\quad 91$

Chapter 5: Formulations and Preparation $\quad 94$

Introduction $\quad 94$

Preparing Resin Mixes $\quad 94$

In Process Testing 95

Published Formulations $\quad 96$

Chapter 6: Pultrusion Machines 101

Introduction 101

Brenner Pultrusion Machine $\quad 102$

Goldsworthy Machines 105

Martin Hydraulics Machines $\quad 110$

Mec-Pro Corporation Machines $\quad 112$

Pultrusion Technology Machines $\quad 115$

Gatto Machinery Development

Corp. Machines

118

Morrison Molded Fiber Glass

Company Machines

Chapter 7: Pultrusion Machine Operation 124

Introduction 124

Calculating Glass Reinforcement

Requirements 124

Pultrusion Machine Start-up $\quad 132$

Pultrusion Resin System Comparison $\quad 134$

Pultruded Flat Sheets $\quad 135$

Annotated Bibliography 
Appendix A: Annotated Bibliography Authors Index By Item Numbers

Appendix B: Glossary 163

Appendix C: Pultrusion Product Trade Names 168

Appendix D: List of trade Names 171

Appendix E: Manufacturers Addresses 173

Appendix F: List of Professional Organizations $\quad 177$

$\begin{array}{ll}\text { Index } & 179\end{array}$ 


\section{Foreword}

We have needed this book for some time. There is a very wide spectrum of management personnel, engineers in continuing education, specifiers, designers, graduate students-not to omit investors-who need this material as an intensive short course and reference work permanently at hand.

Even in recession conditions the pultruded product business has grown by double-digit percentages, and this level of demand will continue as the U. S. infrastructure is renovated. Demand has stirred competition, in turn leading to product refinement. This technology development is taking place in materials, such as processable epoxy systems; in exotic but reliable production systems; and in mold/part complexity.

The Handbook of Pultrusion Technology is essential to orient us in the fundamentals. The substance in Ray Meyer's treatment of this RP process is not available in any other compilation.

Joseph S. McDermott, Manager

Reinforced Plastics/Composites Institute The Society of the Plastics Industry, Inc. 


\section{Preface}

Since my retirement five years ago I have had several opportunities to review my files and draft reports on pultrusion, especially for overseas clients. This book resulted from organizing and updating these reports and filling in some of the gaps in my information.

Basic design information for fiberglass reinforced plastics (FRP) products in general and pultruded products in particular have not been readily available. Mold design data are very difficult to locate. Raw materials information traditionally flows directly from the manufacturer to the pultruder. Several misapplications of information, in the past, have resulted in problem areas. It is with the intent of partially overcoming some of these deficiencies that this volume has been prepared.

Raymond W. Meyer

Tallmadge, Ohio

January, 1985 


\section{Acknowledgments}

There were many contributors who helped in supplying the data in this book. I would like particularly to thank the following: J. Albert Rolston; Ivan Brenner of I. G. Brenner Co., Henry Green of Martin Hydraulics; Jeff Martin of Pultrusion Technology Inc.; David Breck of Goldsworthy Engineering; Ernest Preiato of Gatto Machinery Development; C. W. Bass of MecPro; David Evans of Creative Pultrusions; J. D. Tickle and Nell Campbell of Morrison Molded Fiber Glass; T. S. McQuarrie of Koppers; Ron Rumpler and Sean McMullen of Owens-Corning Fiberglas; Tom Surrant and Tom Pflieger of CertainTeed; A. H. Horner of Silmar; Mike Kallaur of Freeman Chemical; John Dockum of PPG Industries; Bob Talbot and Jack Mitrey of Ashland Chemical, and many others. 